\title{
Assessment of Pedotransfer Functions for Saturated Hydraulic Conductivity of Anatolian Soils
}

\begin{abstract}
Gülay Karahan ${ }^{1, a, *}$
${ }^{1}$ Department of Landscape Architecture, Faculty of Forestry, Çankırı Karatekin University, 18100 Çankırı, Turkey *Corresponding author A R T I C L E I N F O A B S T R A C T

Hydraulic conductivity is an essential base for applied research in soil and water management, landscape, and environmental disciplines. Saturated hydraulic conductivity $\left(\mathrm{K}_{\text {sat }}\right)$ is one of the most important soil physical properties, which is considered in the planning of irrigation and drainage and predicting other soil hydrological processes. However, it has been frequently reported that measurement of $\mathrm{K}_{\mathrm{sat}}$ is laborious, time-consuming, and expensive due to its high spatial variability and this has motivated researchers to develop indirect methods such as pedotransfer functions $\left(\mathrm{PTF}_{\mathrm{s}}\right)$

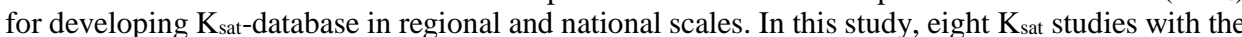
$\mathrm{PTF}_{\mathrm{s}}$ in Anatolian soils were reviewed. PTF were evaluated regarding their type, predictors used, and their performance. The majority of studied PTF $F_{s}$ were developed on alluvial, colluvial, and alkaline soils in semi-arid and semi-humid climates. Multiple linear regression (MLR) and artificial neural networks $\left(\mathrm{ANN}_{\mathrm{s}}\right)$ have been common $\mathrm{PTF}_{\mathrm{s}}$, and soil texture, bulk density, organic matter content, and $\mathrm{pH}$ have been common predictors used with these $\mathrm{PTF}_{\mathrm{s}}$. Root mean squared error (RMSE), mean absolute error (MAE), and coefficient of determination $\left(\mathrm{R}^{2}\right)$ were the commonly used criteria in the verification and validation of the PTFs. Studies on the use of $K_{\text {sat }}$ and PTF are inadequate, and researches are still needed to be able to use it nationwide and can develop an adequate database. According to the results of PTF studies, the highest $\mathrm{R}^{2}$ and correlation coefficient (r) values belong to the Rosetta and MLR types of the $\mathrm{PTF}_{\mathrm{s}}$, respectively. The lowest RMSE value was obtained with the equations in which the physical and chemical soil properties were used together as input data for $\mathrm{PTF}_{\mathrm{s}}$. In addition, it has been noted that the soil morphological properties should be used as input data in $\mathrm{PTF}_{\mathrm{s}}$ studies, especially in $\mathrm{K}_{\mathrm{sat}}$ estimation.
\end{abstract}

Türk Tarım - Gıda Bilim ve Teknoloji Dergisi, 8(5): 1188-1194, 2020

\section{Anadolu Topraklarının Doymuş Hidrolik İletkenliği için Pedotransfer Fonksiyonlarının Değerlendirilmesi}

\begin{tabular}{|c|c|}
\hline M A K A L E B İ L G İ S İ & Ö Z \\
\hline $\begin{array}{l}\text { Anahtar Kelimeler: } \\
\text { Hidrolik iletkenlik } \\
\text { PTF } \\
\text { Kaynak yönetimi } \\
\text { Toprak morfolojisi } \\
\text { Türkiye toprakları }\end{array}$ & 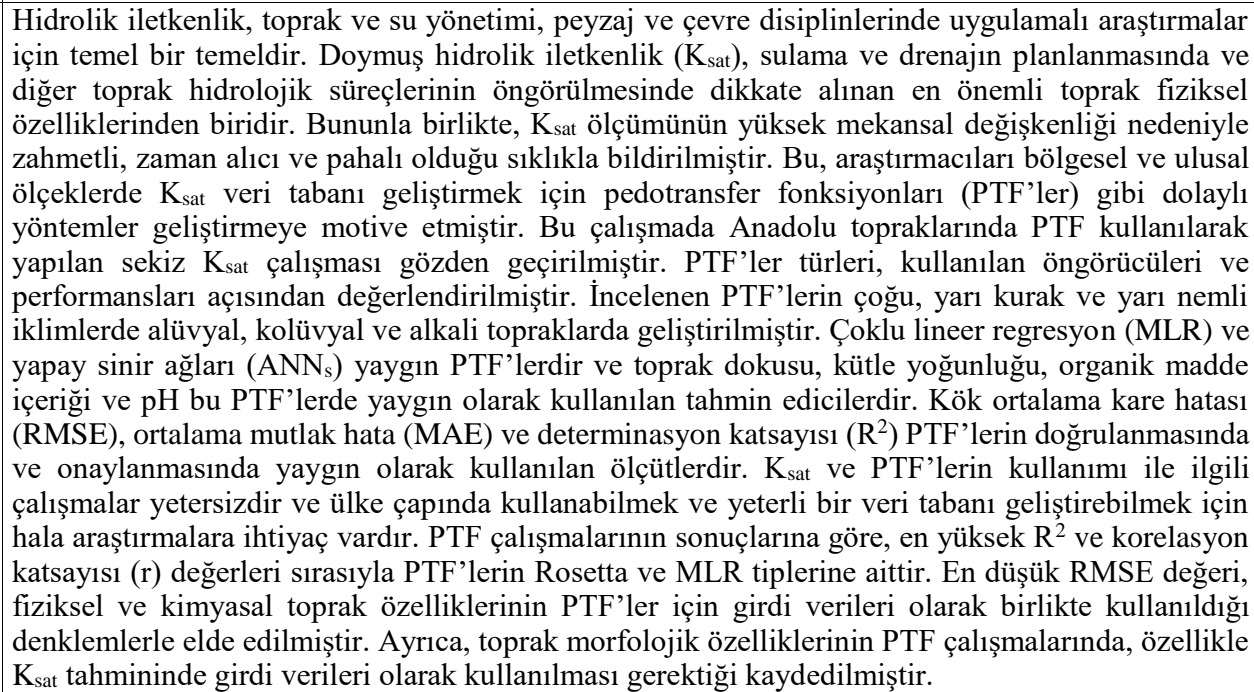 \\
\hline
\end{tabular}




\section{Introduction}

Soil saturated hydraulic conductivity $\left(\mathrm{K}_{\mathrm{sat}}\right)$ is a basic soil characteristic used in modeling of water flow and solute transport in soils. According to Klute and Dirksen (1986), saturated hydraulic conductivity is a soil's ability to transmit water under soil conditions. Knowing the hydraulic conductivity of the soil under saturated conditions is very important because of the high amount of solubility transport and water flow in saturated media (Bagarello et al., 2003).

It can be measured directly in the field by borehole infiltrometer or Amoozemeter methods, or in the laboratory with a permeameter (Klute and Dirksen, 1986; Amoozegar, 1989). The first laboratory measurement of saturated hydraulic conductivity, one of the physical and hydraulic properties of soils, was made in 1856 by Henry Darcy (Stephens, 1996) and the amount of water flowing through a saturated soil column is expressed by the Darcy law (Eq. 1) (Braddy and Weil, 1999).

$$
\mathrm{Q}=\mathrm{KA}_{\mathrm{t}} \frac{\Delta \mathrm{H}}{\Delta \mathrm{L}}
$$

In the equation;

$\mathrm{Q}=$ The amount of water leaving the column at a certain time $\left(\mathrm{cm}^{3} \mathrm{sec}^{-1}\right)$,

$\mathrm{K}=$ Hydraulic conductivity of the column $\left(\mathrm{cm} \mathrm{sec}^{-1}\right)$,

A $=$ Surface area of the column $\left(\pi \mathrm{r}^{2}\right)\left(\mathrm{cm}^{2}\right)$,

$\Delta \mathrm{H}=$ Change in total hydraulic load $(\mathrm{cm})$,

$\Delta \mathrm{L}=$ Change in the depth of the column $(\mathrm{cm})$,

$\mathrm{t} \quad=$ Time $(\mathrm{sec})$.

However, measurement of $\mathrm{K}_{\mathrm{sat}}$ in the field and laboratory are time-consuming, labor-intensive, and expensive processes. It was also noted that the results of direct measurements may not be accurate due to spatial and temporal variability in soil physical and hydraulic properties (Merdun et al., 2006). Therefore, variable limited conditions have led researchers to develop indirect methods that have used different techniques.

Mathematical models have been developed to predict saturated hydraulic conductivity from easily measurable basic parameters due to the importance of $\mathrm{K}_{\mathrm{sat}}$ in the hydrologic cycle. There are many studies contain different models and techniques for predict $\mathrm{K}_{\mathrm{sat}}$ from basic soil properties; empirical (Hazen, 1892; Puckett et al., 1985; Nemes et al., 2005; Parasuraman et al., 2006; GhanbarianAlavijeh et al., 2010), quasi-physical (Kozeny, 1927; Carman, 1937; Ahuja et al., 1984;1989; Rawls et al., 1993; Arya et al., 1999; Timlin et al., 1999), physically-based (Katz and Thompson, 1986; Xu and Yu, 2008; Skaggs, 2011; Porter et al., 2013; Hunt et al., 2014; Ghanbarian et al., 2016), and numerical (Zhang et al., 2005; Elliot et al., 2010; Mostaghimi et al., 2013; Ghanbarian and Daigle, 2015; Dal Ferro and Morari, 2015) (Ghanbarian et al., 2016).

Pedotransfer functions are empirical relationships which commonly used to relate the parameters of models to more readily available data (Pachepsky and Hill, 2017). Pedotransfer functions term was used the first time by Bouma (1989) and it was identified as relationships between soil hydraulic parameters (e.g. $\mathrm{K}_{\text {sat }}$ ) and the easier measurable properties (e.g. bulk density, $\mathrm{pH}$, soil texture) usually available from the soil. According to Pachepsky and Rawls (2004), many models have been developed to quantify $\mathrm{K}_{\mathrm{sat}}$ but pedotransfer functions preferred for $\mathrm{K}_{\mathrm{sat}}$ estimation are commonly done using empirical relationships linking $\mathrm{K}_{\mathrm{sat}}$ to soil basic properties such as textural fraction and organic matter content, etc.

In the past, comprehensive theoretical studies about PTF $_{\mathrm{s}}$ have been done by Wösten et al. (2001), Pachepsky and Rawls (2004), Vereecken et al. (2010), and Van Looy et al. (2017). In recent years, PTF studies have ranged from theoretical studies to small-scale modeling studies (Zhanga and Schaap, 2019). However, literature in prediction of $\mathrm{K}_{\mathrm{sat}}$ using $\mathrm{PTF}_{\mathrm{s}}$ are limited and generally, they restricted to assessments at small scales. In addition, studies have not been able to focus on the $\mathrm{K}_{\mathrm{sat}}$, which still appear to be a critical and complex soil feature and its high spatial variability (Deb and Shukla, 2012; Sarki et al., 2014).

There are many studies about $\mathrm{K}_{\text {sat }}$ and $\mathrm{PTF}_{\mathrm{s}}$ conducted on Anatolian soils. However, we have inadequate paper $\mathrm{PTF}_{\mathrm{s}}$ for predicting $\mathrm{K}_{\mathrm{sat}}$ in Anatolian soils as compared to studies around the world. The use of $\mathrm{PTF}_{\mathrm{s}}$ for $\mathrm{K}_{\mathrm{sat}}$ in Turkey is very new and the first study was done in 2004 by Tombul et al. Candemir and Gülser (2012) also noted that there are limited studies related to the prediction of saturated hydraulic conductivity of fine-textured, especially alkaline soils. The aim of this study is encouraging researchers for new researches by giving information about PTF studies conducted on Anatolian soils. We evaluated the performance of eight published $\mathrm{PTF}_{\mathrm{s}}$ between 2004 and 2016 in predicting the soil saturated hydraulic conductivity for Anatolian soils.

\section{Material and Methods}

\section{Soil Properties}

The examined papers contain the 526 soil samples taken from eight different regions of Anatolia. Although the studied regions represent different climatic and soil characteristics, there are not enough PTF studies for Anatolian soils as seen from the map (Figure 1). A summary of the soil datasets used in this paper was given in Table 1. In addition, methods for measuring the soil saturated hydraulic conductivity were given in Table 2 .

\section{Measurement Methods}

Soil samples were taken from different depths (0-15, 020, 15-30, 30-60, and 60-90 cm). Using predictive input data consisting of soil texture (PSD), bulk density (BD), organic matter content (OM), soil $\mathrm{pH}$, field capacity (FC), permanent wilting point (PWP), cation exchange capacity (CEC), volumetric moisture content (VMC), soil moisture content (SMC), sodium absorption ratio (SAR), exchangeable Na percentage (ESP), specific surface area (SSA), aggregate stability index (ASI), penetration resistance (PR), calcium carbonate $\left(\mathrm{CaCO}_{3}\right)$, soil color, soil depth, and soil morphological properties such as coefficient of linear extensibility (COLE), structure class (SC), structure type (ST), structure size (SS), pore size (PS), pore quantity (PQ), root size (RS), root quantity (RQ), mottles quantity (MQ), soil plasticity, and stickiness. The studied regions have alluvial, colluvial, and alkaline soils and semi-arid and semi-humid climates. 
42

36

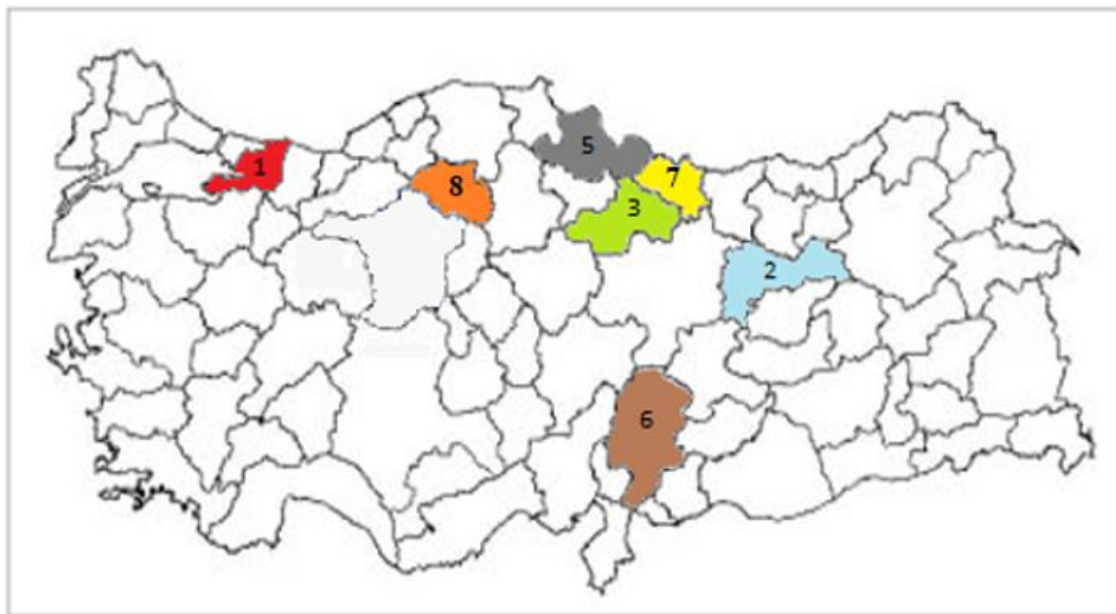

42 Mean- $\mathrm{K}_{\text {sat }} \mathrm{cmhr}^{-1}$

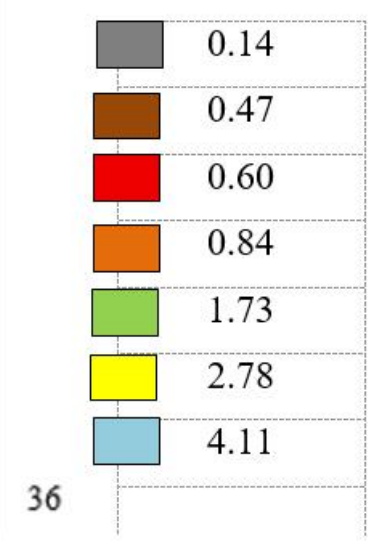

26

45

Figure 1. Soil sampling areas of assessed PTFs studies (P4 not given)

Table 1. Description of datasets used for predicting of $\mathrm{K}_{\mathrm{sat}}$

\begin{tabular}{|c|c|c|c|c|}
\hline Dataset & Location & Samples & Soil properties & Predictors \\
\hline $\begin{array}{l}\text { P1 } \\
\text { Tombul et al. } \\
2004\end{array}$ & $\begin{array}{l}\text { Kurukavak } \\
\text { Subbasin in } \\
\text { Sakarya Basin }\end{array}$ & $\begin{array}{l}\text { Sandy loam (46/2); Loam } \\
(29 / 7) ; \text { Sandy clay; loam } \\
(51 / 2)\end{array}$ & Alluvial & PSD, BD, OM \\
\hline $\begin{array}{l}\text { P2 } \\
\text { Merdun et al. } \\
2006\end{array}$ & Erzincan Plain & $\begin{array}{l}195 \text { cores samples; }(0.2 \mathrm{~m} \\
\text { length and } 0.048 \mathrm{~m} \\
\text { diameter }) ; 0-30, \quad 30-60, \\
60-90 \quad \mathrm{~cm} ; \quad \text { Medium } \\
\text { texture, silt content }(0.447)\end{array}$ & Alluvial & PSD, BD, FC, PWP, AWC, PS \\
\hline $\begin{array}{l}\text { P3 } \\
\text { Öztekin et al. } \\
2007\end{array}$ & $\begin{array}{l}\text { Yesilırmak } \\
\text { Valley }\end{array}$ & $\begin{array}{l}\text { From } 5 \text { profiles; } 19 \\
\text { horizons, undisturbed soil } \\
\text { cores Clay }(\%) 39.13 \text {, } \\
\text { Sand }(\%) 26.36, \text { Silt }(\%) \\
34.53\end{array}$ & $\begin{array}{l}\text { Alluvial over } \\
\text { lacustrine } \\
\text { materials }\end{array}$ & $\mathrm{PSD}, \mathrm{BD}, \mathrm{OM}, \mathrm{CEC}, \mathrm{pH}, \mathrm{VMC}$ \\
\hline $\begin{array}{l}\text { P4 } \\
\text { Haghverdi et } \\
\text { al. } 2012\end{array}$ & $\begin{array}{l}\text { Different parts } \\
\text { of Turkey }\end{array}$ & $\begin{array}{l}91 \text { undisturbed soil cores } \\
(0-30 \mathrm{~cm} \text { depth) Sand (\% } \\
31.9) \text { Silt }(\% 28.6) \text { Clay (\% } \\
\text { 39.5) OM (\% 1.16) BD } \\
(\% 1.19)\end{array}$ & $\mathrm{NF}$ & $\mathrm{PSD}, \mathrm{BD}, \mathrm{OM}$ \\
\hline $\begin{array}{l}\text { P5 } \\
\text { Candemir } \\
\text { and Gülser } \\
2012\end{array}$ & $\begin{array}{l}\text { Bafra Delta } \\
\text { Plain }\end{array}$ & $\begin{array}{l}76 \text { disturbed soil samples } \\
\text { from cultivated lands }(0- \\
20 \mathrm{~cm} \text { depth) mostly fine- } \\
\text { textured clay }(76 \%) \text { clay } \\
\text { loam }(24 \%)\end{array}$ & $\begin{array}{l}14 \% \text { slightly } 66 \% \\
\text { moderate } 20 \% \\
\text { strongly alkaline }\end{array}$ & PSD, SAR, ESP, EC, Na \\
\hline $\begin{array}{l}\text { P6 } \\
\text { Yakupoğlu et } \\
\text { al. } 2013\end{array}$ & $\begin{array}{l}\text { K.Maraş Narlı } \\
\text { Plain }\end{array}$ & $\begin{array}{l}25 \text { disturbed samples }(0-15 \\
\mathrm{cm} \text { depth })(5.5 \mathrm{~cm} \text { diameter } \\
\text { and } 5.0 \mathrm{~cm} \text { height }) \text { Mostly } \\
\text { silty soil Mean } 487 \mathrm{~g} \mathrm{~kg}^{-1}\end{array}$ & $\begin{array}{l}\text { Alluvial } \\
\text { Fluvaquents } \\
\text { Xerofluvents }\end{array}$ & $\begin{array}{l}\text { PSD, BD, SAT, EC, OC, CEC, } \\
\text { pH, FC, PWP, AWC }\end{array}$ \\
\hline $\begin{array}{l}\text { P7 } \\
\text { Gülser and } \\
\text { Candemir } \\
2014\end{array}$ & $\begin{array}{l}\text { Carşamba and } \\
\text { Bafra Plains }\end{array}$ & $\begin{array}{l}30 \text { samples }(0-20 \mathrm{~cm} \\
\text { depth) }\end{array}$ & Alluvial Colluvial & PSD, BD, FC, PWP \\
\hline $\begin{array}{l}\text { P8 } \\
\text { Karahan and } \\
\text { Erşahin } 2016\end{array}$ & Cankırı & $\begin{array}{l}60 \text { samples }(0-15 \mathrm{~cm}) 60 \\
\text { samples }(15-30 \mathrm{~cm}) \text { paddy } \\
\text { field, grassland }\end{array}$ & $\begin{array}{l}\text { Gypsic } \\
\text { Ustorthends }\end{array}$ & $\begin{array}{l}\text { PSD, BD, OM, pH, FC, WP, EC, } \\
\text { CEC, SSA, ASI, PR, CaCO }, \\
\text { Color,COLE, SC, SS, ST, PS, } \\
\text { PQ, RS, RQ, MQ, Consistency, } \\
\text { Plasticity, Stickiness }\end{array}$ \\
\hline
\end{tabular}

P: Paper, PSD: Particle size distribution, BD: Bulk density, AWC: Available water capacity, PS: Pore size, OM: Organic matter, OC: Organic carbon, CEC: Cation exchange capacity, VMC: Volumetric moisture content, SMC: Soil moisture content, SAR: Sodium absorption ratio, ESP: Exchangeable Na percentage, EC: Electrical conductivity, FC: Field capacity, PWP: Permanent wilting point, SD: Saturation degree, SSA: Specific surface area, ASI: Aggregate stability index, PR: Penetration resistance, $\mathrm{CaCO}_{3}$ : Calcium carbonate, COLE: Coefficient of linear extensibility, SC: Structure class, ST: Structure type, SS: Structure size, RS: Root size, RQ: Root quantity, MQ: Mottles quantity, NF: Not found. 
Table 2. Methods of the measuring of $\mathrm{K}_{\mathrm{sat}}$ in $\mathrm{PTF}_{\mathrm{s}}$ used papers

\begin{tabular}{c|l}
\hline PN & \multicolumn{1}{|c}{ Method of the $\mathrm{K}_{\text {sat }}$ measurement } \\
\hline P1 & Measured in Laboratory (no explain) \\
P2 & Constant-head permeameter method with a constant hydraulic head of 0.1 m was used to determine $\mathrm{K}_{\text {sat }}$ on core \\
P3 & The constant head saturated hydraulic conductivity test (Klute and Dirksen, 1986) \\
P4 & Measured with 3 repetitions in the laboratory using by laboratory permeameter instrument. \\
P5 & Measured with the constant head method (U.S. Salinity Laboratory Staff, 1954) \\
P6 & Measured with Mariotte apparatus in laboratory according to Darcy law (Özdemir, 1998). \\
P7 & Determined as defined by the Soil Survey Laboratory (2004). \\
P8 & Measured using a constant-head permeameter (Klute and Dirksen, 1986) \\
\hline
\end{tabular}

Table 3. The list of PTFs equations used for the predicting of the $\mathrm{K}_{\mathrm{sat}}$

\begin{tabular}{|c|c|c|}
\hline $\mathrm{PN}$ & PTF & PTFs equations \\
\hline P1 & Rosetta & $\theta_{\mathrm{h}}=\mathrm{a}^{*} \operatorname{sand}(\%)+\mathrm{b}^{*}$ silt $(\%)+\mathrm{c}^{*}$ clay $(\%)+\mathrm{d}^{*}$ organic matter $(\%)+\mathrm{e}^{*}$ dry bulk density $(\%)+\mathrm{x}^{*}$ variable $\mathrm{X}$ \\
\hline $\mathrm{P} 2$ & MLR ANN & $\mathrm{Y}=\mathrm{b}_{0}+\mathrm{b}_{1} \mathrm{X}_{1}+\ldots+\mathrm{b}_{7} \mathrm{X}_{7}+\mathrm{b}_{8} \mathrm{X}_{1}^{2}+\ldots+\mathrm{b}_{14} \mathrm{X}_{7}^{2}+\mathrm{b}_{15} \mathrm{X}_{1} \mathrm{X}_{2}+\ldots+\mathrm{b}_{\mathrm{n}} \mathrm{X}_{6} \mathrm{X}_{7}$ \\
\hline P3 & MLR & $\begin{array}{l}\mathrm{Y}=\mathrm{b}_{0}+\mathrm{b}_{1} \mathrm{X}_{1}+\ldots+\mathrm{b}_{7} \mathrm{X}_{7}+\mathrm{b}_{8} \mathrm{X}_{1}^{2}+\ldots+\mathrm{b}_{14} \mathrm{X}_{7}^{2}+\mathrm{b}_{15} \mathrm{X}_{1} \mathrm{X}_{2}+\ldots+\mathrm{b}_{35} \mathrm{X}_{6} \mathrm{X}_{7} \\
\log \left(1000^{*} \mathrm{~K}_{\mathrm{v}}\right)=-5.54+3.114^{*} \mathrm{BD}+0.387^{*} \mathrm{OM}-0.00039^{*} \mathrm{C}^{2}-6.3^{*} 10^{-6^{*}}\left(\mathrm{CEC} \mathrm{C}^{*} \mathrm{pH}\right)^{2}+0.013^{*} \mathrm{CEC}+0.048^{*} \mathrm{C}+0.026^{*} \mathrm{~S}\end{array}$ \\
\hline P4 & $\begin{array}{l}\text { Jabro } \\
\text { Pucket } \\
\text { NeuraTheta } \\
\text { Rosetta } \\
\text { Turkey }\end{array}$ & $\begin{array}{l}\log \left(\mathrm{K}_{\mathrm{s}}\right)=\mathrm{a}-\mathrm{b} \cdot \log (\% \text { silt })-\mathrm{c} \cdot \log (\% \text { clay })-\mathrm{d} \cdot(\mathrm{BD}) \\
\log \left(\mathrm{K}_{\mathrm{s}}\right)=\mathrm{a}-\mathrm{b} \cdot \log (\% \text { silt })-\mathrm{c} \cdot \log (\% \text { clay }) \\
\log \left(\mathrm{K}_{\mathrm{s}}\right)=\mathrm{a}-\mathrm{b} \cdot \log (\% \text { silt })-\mathrm{c} \cdot \log (\% \text { clay }) \\
\log \left(\mathrm{K}_{\mathrm{s}}\right)=\mathrm{a}-\mathrm{b} \cdot \log (\% \text { silt })-\mathrm{c} \cdot \log (\% \text { clay })-\mathrm{d} .(\mathrm{BD}) \\
\log \left(\mathrm{K}_{\mathrm{s}}\right)=\mathrm{a}-\mathrm{b} \cdot \log (\% \text { silt })-\mathrm{c} \cdot \log (\% \text { clay })-\mathrm{d} .(\mathrm{BD})-\mathrm{e} .(\mathrm{OM})\end{array}$ \\
\hline P5 & MLR (PTF9) & $\mathrm{K}_{\mathrm{s}}=0.764-2.93 \mathrm{E}-2 \mathrm{C}+1.04 \mathrm{E}-2 \mathrm{Si}-3.46 \mathrm{E}-2-3.50 \mathrm{E}-2 \mathrm{SAR}+0.271 \mathrm{I}$ \\
\hline P6 & MLR & $\mathrm{K}_{\mathrm{sat}}=30.396-0.019 \mathrm{~S}-0.042(\mathrm{Si}+\mathrm{C})+6.501 \mathrm{BD}+10.738 \mathrm{SAT}$ \\
\hline P7 & MLR & $\mathrm{K}_{\mathrm{s}}=-28.9+0.539 \mathrm{C}-0.184 \mathrm{Si}+101 \mathrm{BD}+0.338 \mathrm{FC}-3.69 \mathrm{PWP}-0.0044 \mathrm{C}^{2}+$ \\
\hline P8 & MLR & $=0.565-0.331$ Stickiness +0.184 Structure Grade +0.0625 Pore Size +0.182 Plasticity +0.217 Pore Quantity \\
\hline
\end{tabular}

PN: Paper number; MLR: Multiple Linear Regression, ANN: Artificial Neural Network, $\theta_{\mathrm{h}}$ is the water content at pressure head h and a, b, $\mathrm{c}, \mathrm{d}$, and $\mathrm{e}$ are regression coefficients. $\mathrm{X}$ is any other basic property, $\mathrm{Y}$ is the dependent variable representing each soil hydraulic parameter, $\mathrm{b}_{0}$ is the intercept, $\mathrm{b}_{1}$, $\mathrm{b}_{\mathrm{n}}$ are regression coefficients, and $\mathrm{X}_{1}-\mathrm{X}_{7}$ are independent variables referring to basic soil properties. Ks: Saturated hydraulic conductivity (cm $\mathrm{h}^{-1}$ ), $\mathrm{C}$ : clay (\%), Si: Silt (\%), EC: Electrical conductivity $\left(\mathrm{dS} \mathrm{m}^{-1}\right)$, Na: exch. Na (cmol kg$\left.{ }^{-1}\right)$; ESP: Exchangeable sodium percentage (\%); SAR: Sodium adsorption ratio $\left(\mathrm{mmol} \mathrm{kg}^{-1}\right)^{0.5}$, FC: Field Capacity, BD: Bulk Density $\left(\mathrm{cmg}^{-3}\right)$,

\section{PTFs Used for Estimating of the Ksat}

In published papers, mostly constant-head permeameter (Klute and Dirksen, 1986) method was used for measuring the $\mathrm{K}_{\text {sat. }}$ Generally, multiple-linear regression (MLR), Artificial neural networks (ANN), and Rosetta used for PTF type. The list of PTFs equations used for the predicting of the $\mathrm{K}_{\text {sat }}$ were given at Table 3. Determination coefficient $\left(\mathrm{R}^{2}\right)$, root mean square error (RMSE), mean absolute error (MAE), mean error (ME), mean absolute error (MAE), mean bias error (MBE), mean squared error (MSE), mean residual error (MRE), and average relative percent error (ARPE) were used for model performance.

Different models in which constants and coefficients were developed were used to predicting the $\mathrm{K}_{\text {sat }}$ from other soil parameters with the pedotransfer functions in examined articles; multiple linear regression (Merdun et al., 2006; Öztekin et al., 2007; Candemir and Gülser, 2012; Yakupoğlu et al., 2013; Gülser and Candemir, 2014; Karahan and Erşahin, 2016), artificial neural networks, ANN (Merdun et al., 2006), Rosetta (Schaap et al., 2001)(Tombul et al., 2004; Haghverdi et al., 2012), and Jabro (Jabro, 1992), Puckett (Pucket et al., 1985), Neurotheta (Minansy and McBratney, 2003), and Turkey PTF (Haghverdi et al., 2012) (Table 4).

\section{Results}

In PTF studies examined, MRL was used for predicting the saturated hydraulic conductivity in 6 of 8 papers. The highest values of $\mathrm{R}^{2}(0.96$ and 0.97$)$ were found in Gülser and Candemir (2014) and Karahan and Erşahin (2016), respectively. The highest determination coefficient values for estimating $\mathrm{K}_{\mathrm{sat}}$ were found for medium and clay soil texture classes.

ANN was used for predicting the saturated hydraulic conductivity in 1 of 8 papers. The mean values of $\mathrm{R}^{2}$ (0.698) and RMSE (3.531) were found in Merdun et al. (2006) (Table 4). Rosetta was used in 2 of 8 papers. The values of $\mathrm{r}$ (NF and 0.13 to 0.69 ) and RMSE (0.051 and 1.61) were found in Tombul et al. (2004) and Haghverdi et al. (2012) respectively (Table 4).

Tonbul et al. (2004) used Gupta and Larson (1979) PTFs and they compared with the measured $\mathrm{K}_{\mathrm{s}}$ values for each soil type. They noted that Rosetta SSC-BD- ${ }_{33} \mathrm{Q}_{1500}$ underestimated $\mathrm{K}_{\mathrm{s}}$ values for all three soil groups, Rosetta SSC-BD overestimated $\mathrm{K}_{\mathrm{s}}$ values for sandy loam, but estimates for loam and sandy clay loam were reasonable. Their study shows that texture and bulk density can be considered as good predictors of saturated hydraulic conductivity. In the studies, MRL was generally used as the PTF type for predicting Ks. However, MLR is a timeconsuming method than ANN due to hydraulic parameters are predicted one by one using basic soil properties. According to Merdun et al. (2006), ANN saves time and energy because all dependent parameters are predicted from independent variables simultaneously in ANN.

Öztekin et al. (2007) used PTFs by MLR analysis and compared Ks of two different plain. They found different results for both plains. This result indicated that the performance of the PTFs can be affected by different origin formation of soils, the high variability of soil properties, and the number of samples. Candemir and Gülser (2012) used 
both physical and chemical properties of soils such as exch. $\mathrm{Na}$, ESP, and SAR as predictors for PTFs and they noted that this improved the accuracy and reliability of PTFs. Their limitations were soils containing clay or clay loam textural class, alkaline soil $\mathrm{pH}$, and high exch. Na content.

Yakupoğlu et al. (2013) used some basic soil physical properties and moisture constants for created PTFs. They emphasized the effect of soil hydraulic properties on $\mathrm{K}_{\mathrm{s}}$. According to Yakupoğlu et al. (2013), the reason for the differences in $\mathrm{K}_{\mathrm{s}}$ estimates using PTFs is datasets that have different properties depending on the complex nature of the soils and measurement techniques. In $\mathrm{K}_{\text {sat }}$ modeling studies, soil parametric variables are generally preferred. However, it's well known that a slight change in soil structure has a considerable impact on $\mathrm{K}_{\text {sat }}$ since $\mathrm{K}_{\text {sat }}$ is strongly controlled by soil pores and their geometry and their orientations in soils (Karahan and Erşahin, 2016). Morphological features are based on visual evaluations. However, they must have numerical values for using as input data in PTFs. Karahan and Erşahin (2016) used MRL for predicting the saturated hydraulic conductivity in paddy and grassland soils. They converted morphological properties (such as grade, type, and size of structure and pores, consistency, and roots) to numerical values (scores) to facilitate their use in the correlation analysis. For example, the greater value was given to a property that would match a greater potential $\mathrm{K}_{\mathrm{s}}$-value. Their results were highly promising, suggesting that soil morphological properties can be used besides soil parametric variables in $\mathrm{K}_{\mathrm{sat}}$ modeling studies. They found soil stickiness, structure grade, pore size and quantity, and plasticity are the most effective factor on $\mathrm{K}_{\text {sat }}$. They noted that further studies are needed across different soil and management conditions to adapt to the use of soil morphology in $\mathrm{K}_{\mathrm{s}}$ modeling.

Pore size distribution and bulk density, which are the most common parametric variables in PTFs, have been also the most used input data in these evaluated studies. Except from other physical and chemical properties, Merdun (2006) (only PS) and Karahan and Erşahin (2016) (SS, SQ, ST, PS, PQ, RS, RQ, MQ, COLE, plasticity, and stickiness) are the first and only studies which used soil morphological properties as input data of model (Table 1). The success of the models can be attributed to the effect of these variables on $\mathrm{K}_{\mathrm{sat}}$. Table 1 shows the soil properties of the samples and the input soil data used in these examples. Soil samples are mostly alluvial soils although alkaline and gypsum soil samples. In addition, generally, similar soil properties were used for input data. According to Table 2, as the soil variables used as input are increased, the predictive power of PTFs increased. PTFs that can be used for predicting the $\mathrm{K}_{\mathrm{s}}$ also should be created in different soils with different properties.

Table 4. The list of datasets and PTFs properties on the prediction set

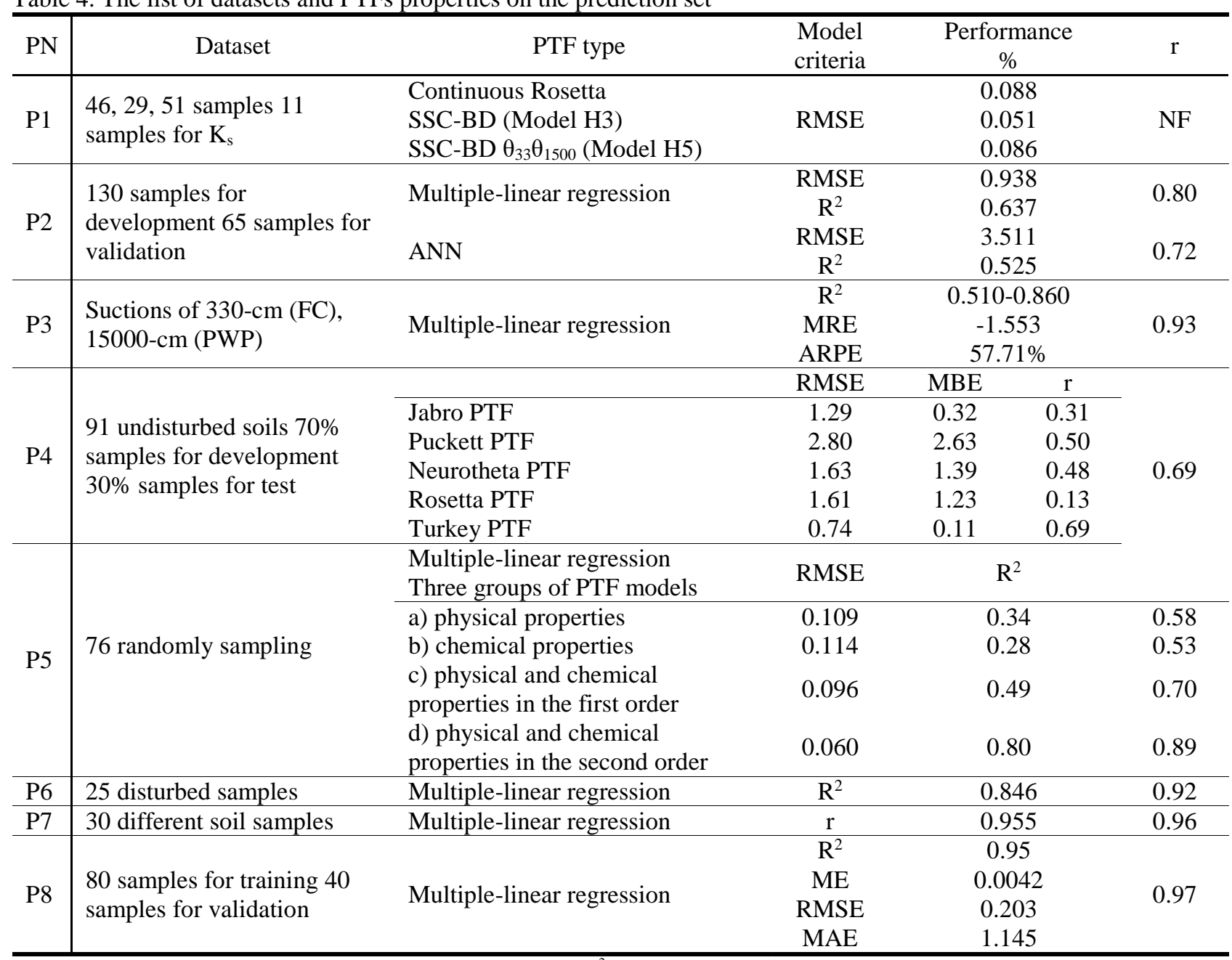

P: Paper, PTF: Pedotransfer function, ANN: Artificial neural networks, $\mathrm{R}^{2}$ : Determination coefficient, r: Correlation coefficient, ME: Mean error, MAE: Mean absolute error, MBE: Mean bias error, MSE: Mean square error, MRE: Mean residual error, RMSE: Root mean square error, ARPE: Average relative percent error, NF: Not found 


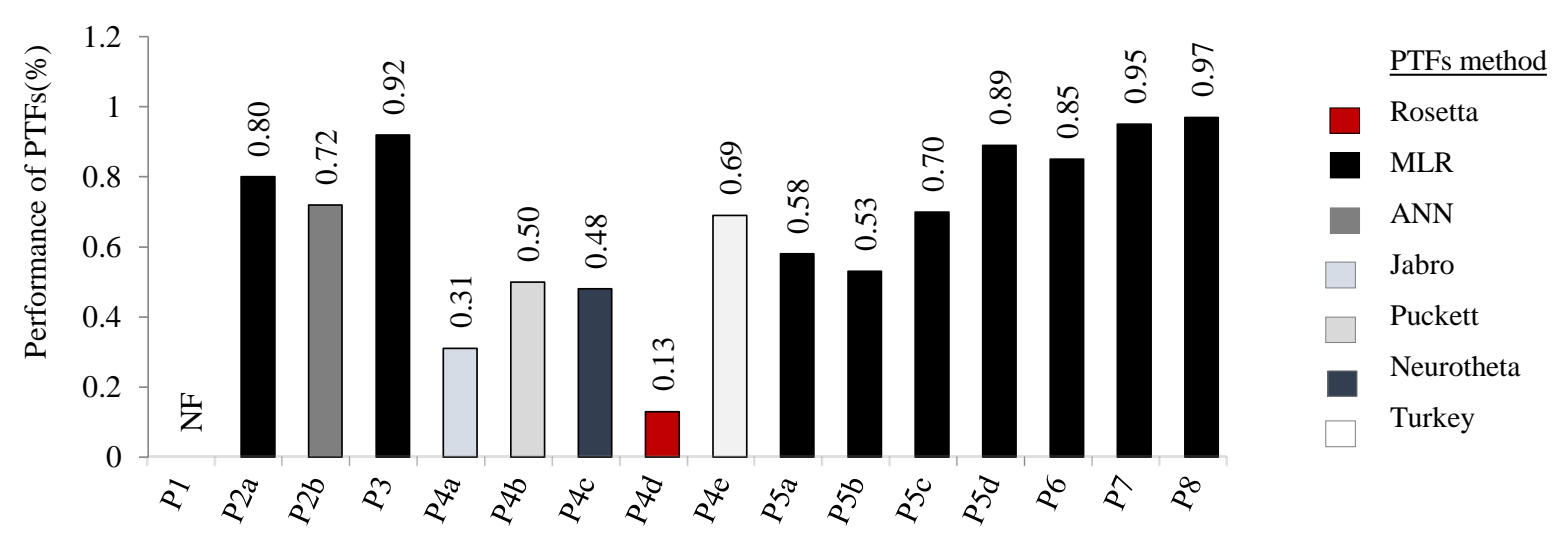

Paper Number

Figure 2. Mean performance of $\mathrm{PTF}_{\mathrm{s}}$ methods according to mean coefficient of corelation (r)

(MRL: Multiple linear regression, ANN: Artificial neural networks, NF: Not found, P5a: PTF input with soil physical properties, P5b: PTF input with soil chemical properties, P5c: PTF input with soil physical and chemical properties in first order, P5d: PTF input with soil physical and chemical properties in second order)

The performance of the PTFs types used for predicting the saturated hydraulic conductivity was compared according to their coefficient of correlation (r) Figure 2. In figure 2, a comparison was made by taking the $\mathrm{r}$ values, which are the common model criterion used in all of the hydraulic conductivity studies for evaluating the performance of PTFs methods. For paper 8, the best model performance occurred with multiple linear regression $\left(\mathrm{R}^{2}\right.$ : 0.97 and 0.95). Published PTF $_{\mathrm{s}}$ based on MLR gave better prediction than Rosetta in these papers. There are a number of studies that compared the performance of PTF $_{\mathrm{s}}$ types. Merdun et al. (2006), Fereshte (2014) noted that MRL showed better performance than ANN.

$\mathrm{PTF}_{\mathrm{s}}$ have some limitations which affect its performance. Schaap and Leij (1998a) noted that PTF were used due to its simplicity and successful results although they have some limitations. Therefore, train (develop) and test (validate) data should be determined correctly as well as soil sampling for the performance of pedotransfer functions (Schaap and Leij, 1998a). Moreover, the number of soil samples should be sufficient and choosing more input variables to correctly represent the field. However, estimating soil properties were restricted to 2-3 soil input properties in evaluated published papers (Tombul et al. 2004; Merdun et al. 2006; Haghverdi et al. 2012; Candemir and Gülser, 2012; Gülser and Candemir, 2014) whereas more soil properties use as input variables will improve the model result. In addition, it is mentioned that some factors such as vegetation, climate, and geography effect soil types and properties and the performance of $\mathrm{PTF}_{\mathrm{s}}$ studies. Because, recent studies in $\mathrm{PTF}_{\mathrm{s}}$ should be focused on the development of better functions to predict soil hydraulic properties for different geographical areas or soil types and determination of the most important basic soil properties as input (Pachepsky and Rawls, 1999). Cemek et al. (2015) also noted that PTF can not perform very well in predicting soil moisture because every PTF is not suitable for all soil types.

In this study, we evaluated 8 papers available in the literature to estimate soil saturated hydraulic conductivity $\left(\mathrm{K}_{\text {sat }}\right)$ using PTFs. The published $\mathrm{PTF}_{\mathrm{s}}$ are inadequate for the prediction and determination of $\mathrm{K}_{\text {sat }}$ for Anatolian soils. Therefore, it is not correct to evaluate the success of the PTFs with only these 8 papers. Even though the study was carried out on the 8 published papers about saturated hydraulic conductivity of Anatolian soils, this study is important with regard to the effect of morphological properties on saturated hydraulic conductivity. Soil morphological properties in addition to physical and chemical properties as input data for predict to $\mathrm{K}_{\mathrm{sat}}$ can improve the model performance. Therefore, future works should test the performance of the PTF's by adding soil morphological properties and these studies should be increased for obtaining a nationwide Ksat database on Anatolian soils. In addition, the $\mathrm{PTF}_{\mathrm{s}}$ have some problems in some conditions. Overall, applying the same PTF under different conditions regions is not correct and does not give reliable results. Therefore, for saving time and labor, and practical for larger-scale applications, studies of $\mathrm{PTF}_{\mathrm{s}}$ should motivate researchers to work on it further. So that estimate saturated hydraulic conductivity using $\mathrm{PTF}_{\mathrm{S}}$ can be possible with a large database that consists of various soil samples from all around the Anatolia. Because it has not been done so far.

\section{References}

Amoozegar A. 1989. A compact, constant-head permeameter for measuring saturated hydraulic conductivity of the vadose zone, Soil Science Society of America Journal, 53: 13561361. DOI: 10.2136/sssaj1989.03615995005300050009x.

Bouma J. 1989. Using Soil Survey Data for Quantitative Land Evaluation. Advances in Soil Science. 9: 177-213. DOI: 10.1007/978-1-4612-3532-3_4.

Candemir F, Gülser C. 2012. Influencing Factors and Prediction of Hydraulic Conductivity in Fine-Textured Alkaline Soils. Arid Land Research and Management. 26: 1,15-31. DOI: 10.1080/15324982.2011.631686.

Cemek B, Arslan H, Güler M, Küçüktopçu E. 2015. Estimation of Field capacity and permanent wilting point using artifical neural network. $2^{\text {nd }}$ International Conference on Sustainable Agriculture and Environment, Konya, Turkey, 9/30-10/3, 2015. Selcuk University, pp.1002-1009, Record Number: 20163289254. 
Deb SK, Shukla MK. 2012. Variability of hydraulic conductivity due to multiple factors. American Journal of Environmental Science. 8 (5): 489-502. DOI: 10.3844/ajessp.2012.489.

Feresthte HF. 2014. Evaluation of artifical neural network and regression PTFs in estimating some soil hydraulic parameters. Proenvironment, 7:10-20.

Ghanbarian B, Taslimitehrani V, Pachepsky YA. 2016. ScaleDependent Pedotransfer Functions Reliability for Estimating Saturated Hydraulic Conductivity. Catena. 149: 37438010.015. DOI: 10.1016/j.catena.2016.10.015.

Gülser C, Candemir F. 2014. Using soil moisture constants and physical properties to predict saturated hydraulic conductivity. Eurasian Journal of Soil Science (EJSS)., 3(1), 77-81. DOI: 10.18393/ejss.69966.

Haghverdi A, Özztürk HS, Ghodsi S, Tunçay T. 2012. Estimating saturated hydraulic conductivity using different well-known pedotransfer functions. Instructions for Short Papers for the Agro Environ Conference, Wageningen; 2012.

Jabro JD. 1992. Estimation of saturated hydraulic conductivity of soils from particle size distribution and bulk density data. Trans. ASAE 35 (2): 557- 560.Karahan G, Erşahin S. 2016. Predicting saturated hydraulic conductivity using soil morphologica properties. Eurasian Journal of Soil Science (EJSS)., 5 (1) 30 - 38. DOI: 10.18393/ejss.2016.1.030-038.

Klute A, Dirksen C. 1986. Hydraulic conductivity of saturated soils. Klute, Methods of Soil Analysis, Part 1. Physical and Mineralogical Methods. SSSA Book Series no.9 $\left(2^{\text {nd }}\right.$ Edition). Madison, Wisconsin, USA. 694-700. DOI: 10.2136/sssabookser5.1.2ed.c28 ISSN: 2156-3276

Merdun H, Çınar Ö, Meral R, Apan M. 2006. Comparison of artificial neural network and regression pedotransfer functions for prediction of soil water retention and saturated hydraulic conductivity. Soil and Tillage Research. 90(1): 108-116. DOI: 10.1016/j.still.2005.08.011

Minasny B, McBratney AB. 2003. NeuroTheta, pedotransfer functions for predicting soil hydraulic properties for Australian soil. Australian Centre for Precision Agriculture, The University of Sydney. http://www.usyd.edu.au/su /agric/acpa.

Özdemir N. 1998. Toprak Fizigi. Ondokuz Mayıs Üniversitesi Ziraat Fakültesi Yayınları, Ondokuz Mayıs University Faculty of Agriculture Publications, No:30. Samsun.

Öztekin T, Cemek B, Brown LC. 2007. Pedotransfer Functions for the Hydraulic Properties of Layered Soils. Gaziosman Paşa Üniversitesi Ziraat Fakültesi Dergisi. 24 (2): 77-86.

Pachepsky YA, Rawls WJ. 1999. Accuracy and reliability of pedotransfer functions as affected by grouping soils. Soil Science Society of America Journal (SSSAJ)., 63: 17481757. DOI: $10.2136 /$ sssaj1999.6361748x.

Pachepsky YA, Rawls WJ. 2004. Development of Pedotransfer Functions in Soil Hydrology. (Pachepsky and Rawls). Developments in Soil Science. Amsterdam, Elsevier. Volume 30, ISBN: 0444517057, ISBN:0166-2481(Series).
Pachepsky Y and Hill RL. 2017. Scale and scaling in soils. Geoderma. 287, 4-30 DOI: 10.1016/j.geoderma.2016.08.017.

Puckett WE, Dane JH, Hajek BF. 1985. Physical and mineralogical data to determine soil hydraulic properties. Soil. Soil Science Society of America Journal, 49, 831-836.

Sarki A, Mirjat MS, Mahessar AA, Kori SM, Qureshi AL. 2014. Determination of saturated hydraulic conductivity of different soil texture materials. IV:56-62. IOSR J. Agric. Veterinary Sci. (IOSR-JAVS) 7 (12). DOI: 10.9790/2380-071245662.

Schaap MG, Leij FJ. 1998a. Database-related accuracy and uncertainty of pedotransfer functions. Soil Science. 163(10): 765-779.

Schaap MG, Leij FJ, Van Genuchten MTh. 2001. Rosetta: a computer program for estimating soil hydraulic parameters with hierarchical pedotransfer functions', Journal of Hydrology, 251: 163-176.

Yakupoğlu T, Şişman AÖ, Karagöktaş M, Demir ÖF. 2013. Toprakların Doygun Koşullardaki Hidrolik İletkenlik Değerlerinin Pedotransfer Eşitlikler İle Tahminlenmesi. SDU Journal of the Faculty of Agriculture/SDÜ Ziraat Fakültesi Dergisi. 8(1): 84-92. ISSN 1304-9984.

Tombul, M., Akyürek, Z., Sorman, A. Ü. 2004. Research Note: Determination of soil hydraulic properties using pedotransfer functions in a semi-arid basin, Turkey. Hydrology and Earth System Sciences. European Geosciences Union, 8 (6): 12001209.hal-00304995.

U.S. Salinity Laboratory Staff. 1954. Diagnosis and improvement of saline and alkali soils. Agricultural Handbook, No. 64. U. S. Govt. Printing Office, Washington, D.C.

Van Looy K, Bouma J, Herbst M, Koestel J, Minasny B, Mishra U, Montzka C, Nemes A, Pachepsky YA, Padarian J, Schaap MG, Tóth B, Verhoef A, Vanderborght J, van der Ploeg MJ, Weihermüller L, Zacharias S, Zhang Y, Vereecken H. 2017. Pedotransfer functions in earth system science: challenges and perspectives. Reviews of. Geophys. 55: 1199-1256. DOI: $10.1002 / 2017 R G 000581$.

Vereecken H, Weynants M, Javaux M, Pachepsky Y, Schaap MG, Genuchten MTV. 2010. Using pedotransfer functions to estimate the van Genuchten-Mualem soil hydraulic properties: a review. Vadose Zone Journal (vzj)., 9: 795-820. DOI: https://doi:10.2136/vzj2010.0045.

Wösten JHM, Pachepsky YA, Rawls WJ. 2001. Pedotransfer functions: bridging the gap between available basic soil data and missing soil hydraulic characteristics. Journal of Hydrology. 251: 123-150. DOI: 10.1016/S00221694(01)00464-4.

Zhang Z, Schaap MG. 2019. Estimation of saturated hydraulic conductivity with pedotransfer functions: A review. Journal of Hydrology. 575 (2019) 1011-1030. DOI: 10.1016/j.jhydrol.2019.05.058. 